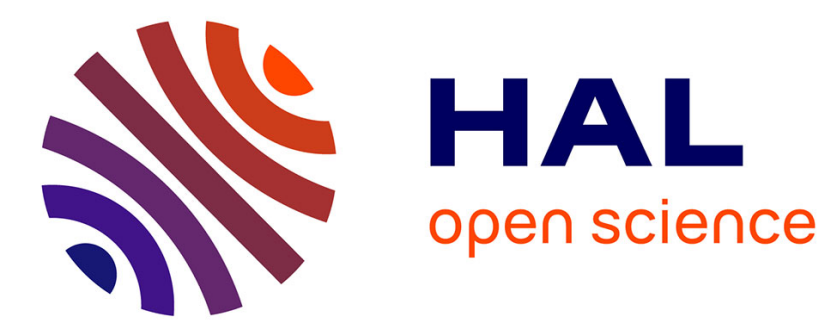

\title{
FDI, social ties and technological learning in new Silicon Valley clones. Evidence from the Costa Rican ICT cluster
}

\author{
Luciano Ciravegna
}

\section{- To cite this version:}

Luciano Ciravegna. FDI, social ties and technological learning in new Silicon Valley clones. Evidence from the Costa Rican ICT cluster. The Journal of Development Studies, 2011, pp.1. 10.1080/00220388.2010.547935 . hal-00722236

\section{HAL Id: hal-00722236 \\ https://hal.science/hal-00722236}

Submitted on 1 Aug 2012

HAL is a multi-disciplinary open access archive for the deposit and dissemination of scientific research documents, whether they are published or not. The documents may come from teaching and research institutions in France or abroad, or from public or private research centers.
L'archive ouverte pluridisciplinaire HAL, est destinée au dépôt et à la diffusion de documents scientifiques de niveau recherche, publiés ou non, émanant des établissements d'enseignement et de recherche français ou étrangers, des laboratoires publics ou privés. 


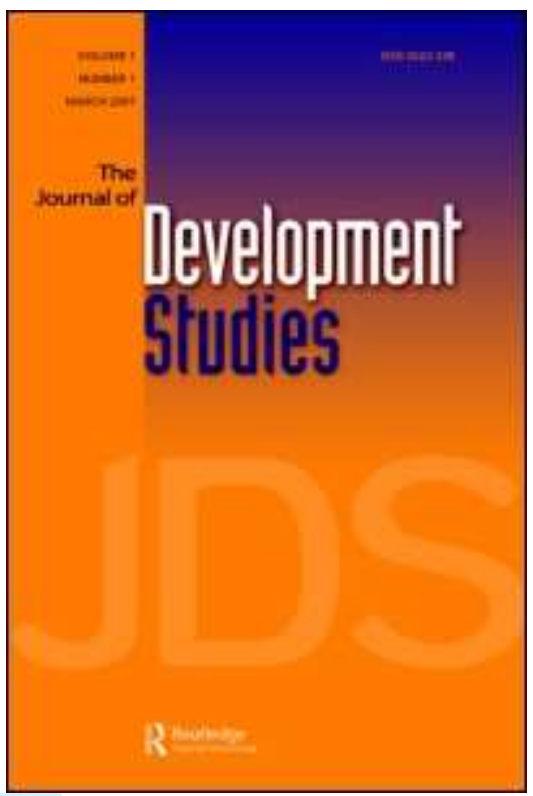

FDI, social ties and technological learning in new Silicon Valley clones. Evidence from the Costa Rican ICT cluster

\begin{tabular}{|r|l|}
\hline Journal: & Journal of Development Studies \\
\hline Manuscript ID: & FJDS-2009-Dec-0015.R1 \\
\hline Manuscript Type: & Original Manuscripts \\
\hline Keywords: & $\begin{array}{l}\text { Industrial development }<\text { Economics, Foreign direct investment }< \\
\text { Economics, Technological learning, Social ties, Latin America }< \\
\text { Geographical Area }\end{array}$ \\
\hline \hline
\end{tabular}

\section{SCHOLARONE ${ }^{\text {TM }}$ \\ Manuscripts}




\title{
FDI, social ties and technological learning in new Silicon Valley clones. Evidence from the Costa Rican ICT cluster
}

\begin{abstract}
1 ABSTRACT
This study, based on qualitative evidence collected through 150 interviews with local entrepreneurs, MNC directors, and other actors, contributes to the understanding of the effects of FDI by showing that the social ties of local entrepreneurs and MNC directors affect technological learning in the Costa Rican ICT cluster in ways that are often overlooked by the literature on technological capabilities. It illustrates that the social disembeddedness of MNC directors and the low endowment of transnational social ties of local entrepreneurs contribute to explain the limited effect of FDI on technological learning in the Costa Rican Silicon Valley clone.
\end{abstract}




\section{INTRODUCTION}

Ireland, Israel, and Taiwan leveraged FDI to develop a globally competitive ICT industry, providing a powerful example for developing countries that seek to foster structural change towards a more sophisticated industrial economy (Breznitz, 2007). A growing number of countries, ranging from Costa Rica to Vietnam, are attempting to create their own "Silicon Valley clones" by attracting investments from the leading ICT multinationals (Rosenberg, 2001; Nelson, 2005).

Attracting FDI is, however, only the first step to create competitive ICT clusters. Unless FDI supports the accumulation of technological capabilities, it may only generate agglomerations of multinational companies that operate in technological enclaves without contributing to local development (Bell, 1984; Lall, 1992; 2003). For example, while multinationals helped Taiwan become an ICT powerhouse (Wade, 2004: pp. 73-155; Breznitz, 2007), Mexico built a high tech assembly site in Guadalajara where MNCs had little effects on industrial development (Altenburg and Meyer-Stamen, 1999). Instead, they quickly relocated as cheaper production sites became available, leaving behind unemployment and pollution (Gallagher and Zarsky, 2008: pp. 121-146). What factors determine the effects of FDI on the development of local technological capabilities in new Silicon Valley clones such as the Costa Rican ICT cluster?

There is a growing body of empirical and theoretical studies that attempt to explain the effects of FDI on industrial development. Some of them address the 
issue by looking at the policies that different countries adopt to attract foreign investment and foster the accumulation of technological capabilities (Lall, 1992; Breznitz, 2007). Other scholars focus on the characteristics of investors (MNCs) and the absorptive capacities of local companies (Dunning and Narula, 2000; Chudnovsky et al, 2008; Criscuolo and Narula, 2008). A third stream of studies take a meso-level, or systemic view of FDI and technological capabilities - their analysis includes not only the main actors involved, MNCs, local companies, government agencies and other organizations, but also the interactions among them (Bell and Albu, 1999; Cassiolato and Lastres, 2000; Figueiredo, 2008).

Most studies, however, overlook the social context in which both MNCs and local companies are embedded. Scholars of international business and MNCs, for example, provide comprehensive explanations of the nature of FDI by analyzing the strategic motives of MNCs' investment (Dunning and Lundan, 1998, pp. 63-78; Dunning and Narula, 2000; Marin and Bell, 2006; Hobday and Rush, 2007). They fail to take into account that the directors of MNC subsidiaries are socially embedded economic actors (see for example Shrank, 2003) and that their social contacts affect their access to information, business opportunities, for example whether to look for local suppliers or not. Drawing from the principles of economic sociology (Powell, 1990; Granovetter, 2005), this paper contributes to the debate by showing that the social ties of MNC directors and local entrepreneurs affect local firms' acquisition of new 
technology and skills in ways that are often not captured by studies that focus only on economic or political variables.

The process through which local organizations acquire technological capabilities is gradual and cumulative. It involves organizations, but also the people who lead them, who often act as bridges for knowledge to flow across the organizational barriers of MNCs and local companies (Lall, 2003). Quantitative analyses of the effects of FDI on technological capabilities may be useful to capture its outcomes, such as the introduction of new products (among others, see Aw, 2002; Caniëls and Romjin, 2003). They may not consider some dimensions of the phenomenon studied, for example the processes through which local firms acquire technology, which change depending on the company and the type linkages that it may have with MNCs (Figueiredo, 2008).

This study, albeit limited to one case of new Silicon Valley in Latin America, provides an in-depth qualitative analysis of technological learning, intended as the process through which local actors first become aware of the need to acquire technology from external sources, such as MNCs, and the mechanisms through which they try to acquire it. The findings show that social ties affect technological learning by shaping access to information and by generating opportunities for MNCs and local companies to create linkages that have positive developmental effects. The evidence presented shows that in order to improve our understanding of the relationships between MNCs and local companies in new Silicon Valley clones and their impact on technological 
learning, it would be useful to corroborate existing quantitative studies with more detailed, firm-level qualitative evidence of the social as well as economic and political dimensions of the phenomenon.

The study is based on fresh evidence collected through direct interviews with 80 local firms, $25 \mathrm{MNCs}$, and representatives of the other actors of the Costa Rican ICT cluster, such as universities and the chamber of ICT producers. The Costa Rican case is relevant because it is a new ICT cluster promoted by attracting FDI with the specific objective of creating a Silicon Valley clone ${ }^{i}$, which has often been looked upon as a benchmark in Latin America (Rodriguez-Clare, 2001; Mytelka and Barclay, 2004; Nelson, 2005; The World Bank Group, 2006).

The paper is structured as follows. First, it briefly describes the Costa Rican ICT cluster. Second, it discusses how the literature on FDI, technological capabilities, and the socially embedded analyses of the ICT industry explains technological learning. Third, it presents primary and secondary evidence of technological learning in the cluster. Fourth, it discusses how other studies of the Costa Rican case explain the outcome. Fifth, it shows how social ties contribute to explain technological learning. 


\section{THE COSTA RICAN ICT CLUSTER}

In the year 1996 Costa Rica attracted a large investment by Intel, outbidding larger and more established competitors, such as Brazil, Chile and Mexico (Nelson, 2005). Other 24 MNCs that operate in ICT invested in Costa Rica after the arrival of Intel. In a very short period of time, Costa Rica successfully developed a cluster of MNCs and local firms operating in ICT related activities, located in the Central Valley area (Porter and Ketelhohn, 2002). By the year 2007 the cluster included also 150 domestic producers of ICT.

INSERT TABLE 1 - The Costa Rican ICT cluster in 2007

The MNCs of the cluster are both software developers and hardware manufacturers. Costa Rican producers are small firms $(75 \%$ of them has less than 20 employees, $5 \%$ has more than 100 employees, none has more than 150 employees) specialised in the development of software applications for enterprises and the provision of customised business services, such as programming and data storage (Lopez et al, 2009).

Largely due to the effects of FDI, Costa Rica's exports of electric and electronic goods increased from $3 \%$ of the total value exports in 1985 , to $28 \%$ in 2003, making it the Latin American country with highest ICT exports per capita (The World Bank Group, 2006). Whether FDI led to technological 
learning is less clear (Paus, 2005: pp. 173-200). The next section introduces the literature on technological learning, before examining how far it has occurred in the Costa Rican case.

\section{LITERATURE REVIEW}

Technological learning, the process through which local firms from developing countries accumulate technological capabilities, entails understanding technological trends, identifying sources from which to acquire technology, implementing strategies of technology acquisition and then adopting, internalizing, modifying, recreating and improving the technology absorbed, up to a stage where companies become able to generate their own, specific technological solutions (Hobday, 1994; Bessant et al, 2001). It is a costly, cumulative and difficult process because technology is not a public good, nor is it easy to access, use, and adjust to local conditions. It is embodied in the machinery, practices and workforce of firms, which jealously protect it from competitors (Lall, 1992; 2003).

Attracting high technology subsidiaries of the leading MNCs can help this technological learning process if there are mechanisms that facilitate the transfer and absorption of technology from MNCs to local organizations (Bell and Albu, 1999; Lall, 2003). The most common of these mechanisms are direct transfers of technology from MNCs to their buyers and suppliers, indirect spillovers (for example by observing the practices of a MNC a local firm can 
learn new organizational techniques) and labour turnover (Bell, 1984; Lall, 1992; Kokko, 1994). There is a rich body of literature discussing the conditions under which technological learning occurs after MNCs invested in a given location.

Dunning, one of founding fathers of international business, underlined that in order to explain the effects of FDI, it is necessary to start from the organizations that carry out FDI, namely, MNCs (Dunning and Lundan, 1998, pp. 295-411). According to this interpretation, the way in which MNCs invest, the nature of their operations and their sourcing strategies determine technological learning. For example, a MNC that invested for efficiency-seeking reasons in a location where labour is cheap and performs "maquila type" assembly operations (where most inputs are imported and most outputs exported), is likely to have few connections to the host economy, and hence, a limited impact on technological learning. On the contrary, a MNC subsidiary that invested to exploit local strategic assets, such as sophisticated suppliers, may be more beneficial for local technological learning (Lall and Narula, 2004). Evidence from the Guadalajara ICT cluster in Mexico corroborates Dunning's argument. MNCs invested in efficiency-seeking operations, established few linkages to local actors and after a few years delocated to China to lower their production costs - their contribution to industrial development was very limited, as they crowded out local companies and failed to foster technological learning (Gallagher and Zarsky, 2007: pp. 121-146). 
Several studies of FDI and development explain the effects of FDI on technological learning by looking at the absorptive capacity of the host economy, which is determined by a varied range of factors, such as previous industrialization experience, infrastructure, human capital, and a minimum level of technical and scientific knowledge (see for example Perez and Soete, 1988; Narula and Marin, 2003). For example, the workforce trained by a MNC may not be able to use its skills if none of the local companies operates in the same industry. This would limit the extent to which labour turnover can facilitate technology diffusion. If the technological distance between MNCs and the host economy is too high, the latter will not be able to offer "complementary assets", preventing the extent to which MNCs create linkages and support the development of technological capabilities (Lall and Narula, 2004).

Other scholars of industrial development underline that it is government policies that affect absorptive capacity, creating, or failing to create, the conditions under which FDI promotes technological learning (Paus, 2005: 1145). The seminal studies of Lall $(1992,2003)$ on industrial development explained how the Asian Tigers developed technological capabilities in high technology sectors by combining policies to attract FDI with state intervention. Wade's (2004, pp. 256-360) and Breznitz's (2007) analyses of Taiwan's industrial development also focus on the role of the state in building mechanisms that favoured technological learning, such as public R\&D agencies, and incentives for MNCs to work with local organizations. 
Borrowing from the literature on innovation systems (Edquist, 1997, pp.129; Lundvall et al, 2002;), some scholars of industrial development emphasise that FDI has more positive developmental effects where technological learning is supported by "learning systems" - systemic interactions between MNCs, local firms, and other organizations that support the absorption and circulation of knowledge (Cassiolato and Lastres, 2000; Mytelka and Barclay, 2004; Figueiredo, 2008). There is evidence that the accumulation of technological capabilities in the ICT clusters of Silicon Valley and Taiwan was indeed facilitated by highly networked learning systems that linked MNCs, small companies, research labs and other organizations (Saxenian, 2000; Ó Riain, 2006).

The missing factor in all of the literature streams discussed above is the social context in which FDI and technological learning occurs: the professionals who lead the MNCs, local firms and related organizations that operate in ICT clusters, as well as the way in which they are linked to each other and embedded in social structures. As many studies by economic sociologists have shown, economic actions are very often - if not always - embedded and affected by social structures (Uzzi, 1996; Shrank, 2003; Granovetter, 2005; Porter et al, 2005). Nelson (2005) points out that Costa Rica's successful attraction of Intel was facilitated by the information acquired by the director of CINDE (Costa Rica's FDI attraction agency) through his contacts with American multinationals. Saxenian (2005) highlights that the rise of the Indian and Taiwanese ICT industries was supported by social ties linking the ICT 
professionals of these countries with migrant communities of electronic engineers and software programmers working in the US, and especially in Silicon Valley. These transnational social ties bridged otherwise divided, spatially distant communities of practice, compensating for information failure. They provided American MNCs with the necessary local knowledge to find suitable partners in the Indian and Taiwanese ICT clusters, whilst also helping the local firms of these clusters acquire access to new business opportunities, clients, and suppliers (Saxenian and Hsu, 2001).

Ó Riain (2006) argues that social, ethnic, and cultural ties with US helped the ICT entrepreneurs of Ireland, Israel, India, and Taiwan penetrate global production networks led by American MNCs. iii

Despite this growing body of empirical evidence showing that the social contacts of ICT professionals contribute to explain the strategies of both the MNCs and smaller companies they lead, most of the studies of FDI and technological capabilities continue to overlook their relevance. On the other hand, most of the socio-economic studies of ICT clusters do not discuss directly the effects of FDI on technological capabilities (Castilla et al, 2000; Saxenian and Hsu, 2001; Saxenian, 2000; 2005). This paper analyzes technological learning in the Costa Rican ICT cluster, one of the most famous Silicon Valley clones in Latin America (Nelson, 2005; The World Bank, 2006), with a framework that combines the insights of the literature on technological capabilities with those of the socio-economic studies of the ICT industry. It looks at how the social contacts of MNC directors and local entrepreneurs 
affect local companies' technological learning from MNCs. By doing so, it links the studies of ICT clusters with the literature on FDI and technological capabilities - two research streams that look at similar phenomena and, given their multidisciplinarity, can be combined to provide a more encompassing understanding of technological learning and industrial development in Silicon Valley clones.

The next two sections explain the research methodology and examine empirical evidence of technological learning combining the information collected from secondary and primary sources. The following section evaluates how the existing studies of Costa Rica explain technological learning in the cluster. The last section shows how the social ties of entrepreneurs and MNC directors contribute to explain technological learning.

\section{METHODOLOGY - TECHNOLOGICAL LEARNING}

As Pietrobelli et al state, "Technological change is neither exogenous nor automatic, but rather it is the result of purposeful activities, in other words of 'technological efforts', undertaken by firms" (Pietrobelli et al, 2006: 5). Borrowing from the literature on technological capabilities (Bell, 1984; Lall, 1992; Hobday, 1994), "technological learning", has been conceptualised as the process through which local firms become aware of the need to acquire new technical knowledge, and adopt specific strategies to do so. 
"Technological learning" has been used instead of changes in technological capabilities because the objective was to identify technological learning processes and explain how actors' social ties affected them rather than providing a detailed taxonomy of the outcomes of technological learning, such as the introduction of new products and processes.

Bessant et al (2001) developed a methodology to analyze the technological learning curve of firms. They argue that some of the crucial first steps are "technology awareness" and "search" for potential sources from which to acquire it. This research focused on these two aspects of technological learning, collecting qualitative information on Costa Rican ICT entrepreneurs' perception of technology, how important it is for them to be technologically updated, and the strategies they use to acquire technology. Local entrepreneurs were asked to identify the sources from which they acquire technical knowledge, for example publications, MNCs in the cluster, universities, government agencies, sectoral organizations, local clients, or foreign organizations.

This research also collected information on how social ties affect technology awareness and technology acquisition. Social ties have been conceptualised as the personal contacts that local entrepreneurs and the directors of MNC subsidiaries have in the ICT industry, both at the local and transnational level, and which they use as firm-level resources (for example, to acquire information, find business opportunities and request technical advice). The interviews collected information on social ties by asking the interviewees to 
identify the people they rely upon when they need information, technical assistance or some advice in their business.

Local entrepreneurs were asked to specify whether they have contacts to MNC directors in Costa Rica and ICT professionals outside of the cluster, or if their main social contacts in the ICT industry were other Costa Rican entrepreneurs. They were then asked to explain whether and how these contacts influenced their technology acquisition processes, and also the relationships they establish (or attempt to establish) with MNC subsidiaries in the cluster. The directors of MNC subsidiaries were asked to talk about their contacts in the local ICT industry, and explain whether and how these affected their relationships with local firms in the Costa Rican cluster.

Data collection was conducted between June 2004 and April 2008. Camtic, the Costa Rican chamber of ICT producers, provided a database of the local producers, which was refined and filtered by the author by contacting all the companies listed by telephone to check that they were still commercially active. The interviews targeted the 110 local firms out of 150 which had been operational for longer than two years and had a turnover of over 20.00 US \$ per year when contacted, following criteria suggested by industry experts to exclude companies that are not yet, or have never been, fully operational. 80 out of the 110 companies contacted accepted to be interviewed.

The interviews were open ended and semi-structured, based on a questionnaire that asked to identify means of technology acquisition, use of social contacts, and, in case there were linkages with MNCs, mechanisms of 
technological learning through such linkages. They were conducted by author and a research assistant in Spanish and lasted an average of one hour. They were not recorded in order to minimise the researcher's interference on the interviewees' reconstruction of past events, perceptions, and strategies. The interviewers recorded quotes and information on a notepad, and subsequently used these to compile the tables shown in this study. The interviews were held with the Directors of MNCs and the CEOs of local firms, or, when this was not possible, the highest member of senior management available. Follow up visits and informal conversations with ten local entrepreneurs collected further qualitative information on the use of social ties as a means to acquire information and technology from external sources.

The lists of MNCs that invested in Costa Rica were obtained from CINDE, the Costa Rican investment attraction agency, and Procomer, the export promotion agency. These lists were filtered in order to focus only on MNCs that produce ICT goods and services, which in the case of Costa Rica were manufacturers of semi-conductors and related components, providers of databases, operating systems, and services to manage software packages. The 25 MNCs that complied with these criteria were contacted and interviewed either telephonically or through direct visits to their offices. The MNCs that have linkages with Costa Rican firms were visited a second time to clarify mechanisms through which MNCs facilitate the technological learning of their local partners, for example verifying whether they carry out joint activities, 
provide technical assistance, and how often they communicate with their local partners.

Representatives of the government, Camtic (the Costa Rican chamber of ICT producers), CINDE (the investment attraction agency) and Costa Rica Provee (the state agency in charge of facilitating the formation of MNC - local firms' linkages) were also interviewed to collect further information on the cluster. The next section of this study presents the empirical evidence of technological learning in the Costa Rican ICT cluster.

\section{EVIDENCE OF TECHNOLOGICAL LEARNING FROM MNCs}

Some of the studies of the Costa Rican ICT cluster argue that Intel is supporting the technological learning of Costa Rica in the ICT sector through the following means. Firstly, it upscaled its investments in Costa Rica, so that it now performs not only assembling and testing, but also advanced $R \& D$ operations. Secondly, it cooperates with local universities in the establishment of updated curricula. Thirdly, it is providing training to its suppliers (RodriguezClare, 2001; Mytelka and Barclay, 2003; Mortimore and Vergara, 2004; Nelson, 2005; The World Bank Group, 2006).

Paus and Gallagher (2008) contradict this view. They show that MNCs purchases of local inputs are minimal, especially in the ICT industry. Moreover, instead of increasing, they have decreased through time: in 1997, when Intel began producing, local expenditure by multinational machinery and electrical 
components producers (mainly micro-processors manufacturers) was $6 \%$ of the value of their imports. While the value of their total output per year increased progressively through time, the share of their expenditure purchased locally decreased to a record low $2 \%$ of their expense on imported inputs in 2005 . On the basis of this evidence, they argue that FDI had limited effects on technological learning.

Giuliani (2008) analyzes the effects of FDI by looking at a different variable - knowledge flows in the cluster. She finds that knowledge circulates mainly among MNC subsidiaries, whereas there are few knowledge transfers between MNCs and local firms, especially in the case of high technology, export oriented plants, such as the micro-processor manufacturers and service providers of the ICT cluster. This points that although Intel may have attracted investments by other ICT multinationals, there are limited mechanisms through which local firms acquire technology from MNCs.

Intel and other MNCs train their suppliers. Nonetheless, these training programs have a limited effect on technological learning in the cluster because most local suppliers are firms that provide services unrelated to ICT, such as packaging materials (Paus, 2005, 173-200; Ciravegna and Giuliani, 2006). Intel carries out its sophisticated R\&D operations in a highly secluded lab, with no interactions with local actors (Ciravegna, 2009a). As a result, these activities have not, so far, contributed to technological learning in the cluster.

The interviews conducted for this research with MNCs and with Costa Rica Provee corroborate Paus' finding that only a few MNCs (four) have linkages 
with local ICT firms (2005: pp. 173-200). However, this study also found that the four MNCs that have links with Costa Rican ICT producers established 45 linkages. There are three types of linkages: product distribution, product adaptation and product development (Table 2). The vast majority of linkages are of the first type, with only six of the second, and one of the third.

INSERT TABLE 2 - Three types of MNC-local firms' linkages

In product distribution linkages local firms act as distributors for MNCs, which in exchange provide to them discounted technology solutions (mainly databases and operating systems), training courses on how to use such technologies, and a certificate that confirms that they are official distributors for the MNC. The main incentive for MNCs is that local partners distribute their products bundled with the software applications they develop.

Technological learning occurs mainly through standardised technical support that is provided by MNCs with online training courses, and, more seldom, courses held at the MNC subsidiary office for all of the distributors. The technical knowledge MNCs transmit to their partners is exclusively related to the use of their technology. The technical assistance they provide is not on demand, targeted, or related to the specific activities of their partners. One producer explained his product distribution linkage with the following words: 
"Basically we commit to use their technology, they help us use manage it better. If we base all our services only on their technology, they give us discounts, and send us online training courses on how to use it more efficiently. We do not really work with them. We develop our own applications in house and see them (the MNC) only if we go to a big fair, for example an event when they invite all of their distributors to introduce a new product,iv

INSERT TABLE 3 - Reasons for being in product distribution linkages

When asked why they are in product distribution partnership with MNCs, most companies pointed to the discounts and free training courses they receive (Table 3). Only six state that their key objective of being distributors was to engage MNCs in other types of relationships. Four of the latter are already involved in product adjustment and development linkages, two of them are attempting to do it, an issue which is discussed further in the following sections of this study. With regards to technology use, all distributors claimed that they already knew how to use the MNC technology, and being in these linkages just provided a marginal improvement of their mastery of it. No firm claimed to be a product distributor in order to obtain support in product development or basic research from MNCs. As one of them emphasised: 
"We used their technological platform before. The only difference is that now that we are distributors we have the right to get some benefits, such as a few discounted training sessions and online support on how to use their technology. Generally we don't really need much support, using their technology is not very complicated. The hard task is developing new software applications, but that we do by ourselves"v

Product adaptation linkages involve local firms that have been hired by MNCs to adjust an existing product or service to the conditions prevailing in Costa Rica, Central America, or, in some cases, Latin America. In these linkages technological learning occurs through different means: MNCs transmit to their partner technical information and help them to absorb it by providing technical assistance in the product development phase. In four of the six cases MNCs sent teams of engineers to work on-site at the Costa Rican firm's offices, in the other two the MNCs invited the engineers of the Costa Rican firms to their facilities. One of the Costa Rican entrepreneurs involved in product adaptation described his experience with the following phrase:

"The best thing about our relationship is that in order to complete our contract, they (the MNC) had to work with us and let us access at least some of their most strategic technologies. Working with partners of this type (the MNC) allowed us to see how they organise their product development, how they manage their processes.....,i 
One of the product adjustment linkages transformed after four years into a product development linkage. In this case the MNC, impressed with the technical capability of its local partner, asked it to develop a new software application for all of its subsidiaries. In order to do so, it invited the founder of the Costa Rican firm to discuss technical issues with its core R\&D department at the US headquarters. The MNC provided some of its researchers to the Costa Rican firm so that they could carry out joint research into how to better develop a technological solution that would be adopted by the whole corporate network.

The Costa Rican entrepreneur confirmed that this transformed his company, putting it through severe competitive pressure, but also providing it with access to the MNC technical knowledge and to assistance during the problem-solving cycles that, in his description, characterise the development of a new technology (in this case, a new software application to be integrated with the several components of the MNC corporate information system, such as databases and other applications). This Costa Rican firm is now an established global supplier for the MNC, having outcompeted larger rivals from the US and Europe.

Summarizing the results, in the 45 product distribution linkages technological learning was circumscribed to support in the use of the technology of MNC partners, and limited technical assistance to Costa Rican distributors. Only in the product adaptation and product development linkages, 
which are scarce in the cluster, there was evidence of strong technological learning from MNCs, supported by multiple mechanisms of technology acquisition: training, ad hoc visits, technical assistance during product development, and joint $R \& D$ (Table 2).

Half of the 80 firms interviewed do not have linkages with MNCs in the cluster, and do not currently hire staff that was trained in MNCs. Hence, their technological learning is not related to the presence of MNCs. Costa Rican entrepreneurs pointed out that labour circulation from the MNCs that operate in electronics has not, thus far, contributed to technological learning. The main reason is that MNCs pay higher salaries, and thus it is very common for ICT professionals to move from local firms to MNCs, but less common and even unusual to move in the opposite direction. Another reason is that the vast majority of employees of MNCs are technical workers in hardware manufacturing, whereas Costa Rican firms need mainly programmers and software developers. The findings complement some of the arguments of both Paus (2005: pp. 173-200) and Giuliani (2008). Although there are more linkages than they suggest, most of these are product distribution linkages, which support technological learning only in a very limited sense - improving local firms' mastery of a MNC technology that they already manage. What factors explain this outcome? 


\section{EXPLAINING TECHNOLOGICAL LEARNING IN THE CLUSTER}

\section{7a Socially disembedded explanations}

Paus (2005, pp. 135-200) analyzes the effects of FDI on industrial development in Costa Rica by looking at the determinants of foreign investment and the policies adopted by Costa Rica to stimulate the development of technology intensive clusters. She argues that MNCs invested for efficiency seeking reasons, and operate in export processing zones, where they are exempt from import duties and, temporarily, from corporate taxation. Lack of targeted policies to support the creation of linkages between MNCs and local firms hinders the effects of FDI on technological learning. Paus and Gallagher (2008) also point out that Costa Rican companies may not have the necessary competencies to work with MNCs, which also limits the extent to which FDI contributes to technological learning. Giuliani's (2008) main explanation is that the technological gap between MNCs and local firms is too high - or, in other words, local absorptive capacity is insufficient - for linkages and knowledge flows to develop. Her analysis suggests that ICT producing MNCs operate a technological enclave similar to the Guadalajara ICT cluster (Altenburg and Meyer-Stamen, 1999).

Another factor that may limit technological learning from MNCs is the absence of a supporting "learning system" that facilitates the transmission, diffusion and absorption of knowledge (Ciravegna, 2009a). Most local firms and 
all the MNCs that have R\&D departments carry out their R\&D in house, without interacting with other actors. ${ }^{\text {vii }}$ State agencies are not directly involved in activities related to the acquisition, diffusion or absorption of ICT technology. Universities work with MNCs only for the definition of curricula but do not carry out joint research with them. Non governmental agencies, such as Camtic, the chamber of ICT producers, provide information but do not have the necessary means to finance or directly facilitate the acquisition and diffusion of new technology (Paus, 2005: pp. 173-200).

The different interpretations hereby discussed suggest that several factors limit the potential effects of FDI on technological learning: insufficient incentives for MNCs to source locally, incompatible specialization of the MNCs attracted (mainly hardware manufacturing) with the existing pool of local producers (mainly software developers), technological distance between MNCs and local firms, and lack of a supporting "learning system". The next section presents evidence that the social ties of the actors involved explains aspects of technological learning that other studies of the Costa Rican ICT cluster failed to capture.

\section{7b Social ties and technological learning}

When asked about how they acquire technology, local firms point out that personal contacts in the industry are one of their most important sources (see 
Table 4). Their reason for relying on social ties is that they feel that the information that they could access by subscribing to technology research magazines and other formal sources is only occasionally relevant. They point out that these services are tailored to US or first world customers, and as such fail to consider the challenges of operating in developing countries. For example, they often assume a minimum scale of operations that is large by the Costa Rican standards in the ICT sector - the largest domestic company has about 120 employees, and sells less than 20 million US \$ of services per year. The information they acquire from their local and transnational social ties is, they claim, more "filtered", or suited to their needs. One entrepreneur explained:

"We read all of these publications and online things, but here we face different problems...how does it help to know that there is a technology solution that is perfect for my firm if it costs a million dollars? I ask my friends instead, they may have an inferior technical knowledge but at least they know what I need and what I can afford...,

INSERT TABLE 4 - Social ties and technological learning

Interestingly, the entrepreneurs who rely on foreign sources to acquire technology prefer direct contacts for similar reasons. One of them pointed out that: 
"My colleges abroad understand the kind of difficulties we face. When they help us, they do it in a way that is suited to our conditions. There is no technical forum or magazine that can be more usefulpix

The finding is consistent with the studies of social networks that underline their importance as means to acquire information. Quoting Granovetter: 'Much information is subtle, nuanced and difficult to verify, so actors do not believe impersonal sources and instead rely on people they know (Granovetter, 2005: 33). There are 18 local entrepreneurs who, through previous work experience, studies, or kinship, have social ties with ICT professionals abroad (or transnational social ties), which they use as sources of information and technical advice. Eight of them direct older and larger firms, which employ 100 or more people and have been operational since the late 1990s. The other twelve direct firms that have on average 30 employees and were founded after the year 2000. Notably, entrepreneurs with transnational social ties lead all of the firms involved in product adjustment and product development linkages, and also all the firms that that have linkages to firms located outside of the cluster. In other words, they lead the companies that have the types of linkages with MNCs that provide better opportunities for technological learning.

INSERT TABLE 5 - Technological awareness 
Entrepreneurs with transnational social ties showed to be more worried about the need to acquire technology (Table 5). One of them clarified how his social ties to professionals operating abroad affected his perception of technological learning:

"Everything is slower here, even in the high technology sector. Products arrive later, competition is less intense. I travel to see my colleagues in Silicon Valley quite often, and talk to them at least once a week. And I get scared of how fast things move over there. So I try to learn, to understand how they do things over there, and implement it here. Although here there is less competition, sooner or later the trends that you can see now in the US arrive here. And it is better to be ready than to remain technologically backward and then get wiped out by some multinational"x

The quote summarises a common feeling expressed by entrepreneurs who have transnational social ties. They provided evidence that through their transnational social ties they gained additional "technological awareness", which in turn led them to develop specific strategies of technology acquisition.

INSERT TABLE 6 - Perception of MNCs as means to foster technological learning

Entrepreneurs who acquire information through their contacts to ICT professionals located outside of the cluster also have a different perception of 
MNCs. Twelve of them are either already involved in product adjustment and product development linkages, or they are attempting to convince MNCs to hire them. These entrepreneurs explain that their main driver for working with MNCs is precisely to improve their technological, organizational and commercial knowledge (Table 6). A Costa Rican ICT producer who is negotiating a product adjustment link with a MNC explained:

"This (being in a product adjustment linkage) is not about the money. MNCs are though negotiators. We could get much better deals with large local firms. But by working with BBB, we can learn. It will be like an intensive course in ICT technology...let's hope we graduate with a good grade!"xi

Three of the entrepreneurs involved in product adaptation admitted to have accepted contracts with MNCs that brought them to almost bankruptcy just to pursue technology acquisition. Despite low financial gains from these relationships, they argued that they were beneficial because, in their words they "learned a lot".

Six of the entrepreneurs with transnational social ties are also linked to foreign firms (not located in the cluster), with whom they develop products and services, and exchange mutual technical assistance. ${ }^{\text {xil }}$ All of the companies lead by entrepreneurs who have transnational social ties are either trying, or plan to try, to engage MNCs in product adjustment and product development linkages (Table 7). This shows that the social contacts of local producers, and 
especially their links to ICT professionals abroad, determine both their technological awareness and the extent to which they attempt to exploit the presence of MNCs in the cluster to pursue technological learning.

The Costa Rican entrepreneurs who do not have transnational social ties, including the founders of three of the top fifteen domestic firms in terms of average sales per year, tend to be less concerned about acquiring new technology and being technologically updated than their peers who do have transnational social ties (Table 5). Many of them claim that their main preoccupation is not becoming more innovative or acquiring new technology because these are not necessary to make profits in the markets of Central America.

An interesting and unexpected finding was local firms' lack of consideration of MNCs as a means to support their technological learning (Table 6). Entrepreneurs who lack transnational social ties are less preoccupied with the need to acquire technology. They also consider MNCs as a less relevant potential source of technology than entrepreneurs who do have transnational social ties. As a result, many of them do not approach MNCs to work with them.

INSERT TABLE 7 - Strategies to acquire technology from MNCs

The local producers without transnational social ties who do work with MNCs do not attempt to establish product adjustment and product development linkages, which have a higher effect on technological learning (Table 7). They 
are content to remain product distributors because "learning" from MNCs is not one of their objectives.

The findings illustrate the effects of local entrepreneurs' personal contacts, and in particular their transnational social ties, on their technological awareness, and on the type of relationships they attempt to establish with MNCs, which in turn affects technological learning.

Social ties also affect, albeit to a lesser extent, the strategies of MNCs. Most MNC directors are expatriates on temporary assignments. They are socially disembedded - they often do not speak Spanish and have very few, if any, contacts with Costa Rican ICT entrepreneurs. The social ties they leverage when they need advice or technical assistance are with other foreign expatriates working in Costa Rica, or with ICT professionals working abroad. As a result, their understanding of the Costa Rican ICT cluster is limited to the information that is available from formal sources, such as publications and databases, which, at the time of the fieldwork carried out for this study, were incomplete and outdated. Unsurprisingly, MNC directors showed to have a very scarce knowledge of the cluster where they operate, and especially of the local firms.

Part of this lack of understanding of the cluster stems from the fact that, as Paus (2005: pp. 173-200) argues, most MNCs do not need to know about local producers because they can import all of their inputs free of duties. Nonetheless, information failure also plays a role. For example three MNC directors claimed to have specific mandates from the headquarters to find local 
partners for product adaptation tasks but argued that lack of reliable information made it difficult to establish these linkages with Costa Rican ICT producers. Two of them have established linkages with some of the oldest Costa Rican companies, the only ones about which there is reliable information. These two MNC directors argue that their bosses in the US expected them to create a large number of local product adaptation linkages, which they failed to do because they struggle to identify the specialisation and competencies of Costa Rican ICT companies. They concede that there may be several suitable partners in the cluster, and they simply do not know how to find out about them. The third MNC director did not establish any linkage. He interrupted the interview to ask for help in developing an accurate list of Costa Rican ICT producers.

The findings hereby presented show that the scarcity of linkages between MNCs and local companies in the Costa Rican cluster does not necessarily entail that MNCs lack incentives to have local partners, or that local companies are insufficiently competent to work with MNCs, as argued by previous studies (for example Paus and Gallagher, 2008; Giuliani, 2008). Even when MNCs have incentives to create linkages that foster technological learning, they may not do so because they lack access to information about the specialization and competencies of local firms.

The social disembeddedness of MNC directors contributes to this information failure. The only MNC director interviewed who was a Costa Rican citizen showed to have a very different perspective and a superior 
understanding of the cluster. He explained how he used his contacts in the cluster to find suitable local partners:

"I can approach local firms and hire them for complex tasks because I know the entrepreneurs.... studied with many of the directors of Costa Rican technology firms. I talk often to them and this gives me up to date information about who does what, which firm is growing...I also know who I consider to be a reliable professional and would like to have on board as a partner..."xiii

He clarified that he intends to remain in Costa Rica. Ensuring that the Costa Rican subsidiary performs well and has multiple local partnerships will help him achieve this. He added that ensuring the subsidiary grows is not only good for his career but is also a matter of national pride. His contacts in the Costa Rican ICT community affected the strategic decisions he took directing a MNC subsidiary, and also allowed him to pursue a range of opportunities with local firms that socially disembedded MNC directors may not have been aware of.

The director of the global rival of this MNC, which also operates in Costa Rica, provided an opposite account. He is a foreigner who has no social contacts to Costa Rican entrepreneurs. He explained that he was frustrated with his search for local suppliers for the MNC subsidiary he directed. He stated that he never quite knew which ones were good and which ones were bad, or how to find reliable information about them, except for the few that were very 
well known. He confirmed that if it had not been so difficult to find information, the MNC would have many more local partners to perform product adaptation tasks. His account shows that MNC subsidiaries led by directors who are have social linkages with the host country's professional community may have a higher chance to contribute to technological learning because they may have more incentives to establish local linkages and can rely on their social contacts to find suitable local partners in contexts affected by information failure.

\section{CONCLUSION}

The literature on the formation and development of ICT clusters shows that social contacts play an important role in explaining the formation of inter-firm linkages, including the MNC-local firms linkages that foster technological learning (Castilla et all, 2000; Saxenian and Hsu, 2001). However, most studies of FDI and technological capabilities focus on macro-level political and economic variables, failing to take into account the social context in which FDIdriven technological learning occurs (see for example Aw, 2002; Caniëls and Romijn, 2003; Marin and Bell, 2006; Chudnovsky et al, 2008).

This study discussed how local firms acquire technology from MNCs in the Costa Rican ICT cluster. It showed that the social ties of MNC directors and local entrepreneurs affect technological learning in different ways. Local entrepreneurs who have transnational social ties to ICT professionals are more concerned about the need to acquire technology and be technologically 
updated. They engage the MNCs of the cluster with the specific objective of "learning" from them. As a consequence, they attempt not just to work with MNCs, but also to become involved in product adaptation and development linkages, which entail more opportunities to acquire technology, information and skills. On the contrary, entrepreneurs who lack transnational ties do not attempt to use MNCs as a source for their technological learning.

The social contacts of MNC directors influence their incentives for establishing linkages with the host economy and also their access to the necessary information to find local partners. Except for one, all MNC directors lack social contacts with ICT professionals in Costa Rica. This contributes to explain their lack of information about local companies and hence their failure to establish more numerous product adaptation and product development linkages - the linkages that have the most positive effects on technological learning - even in the cases where they have a specific mandate to do so.

This study provides evidence that technological learning in the Costa Rican cluster has been so far hindered by two factors that previous research did not identify. First, the majority of local entrepreneurs lack social ties with professionals abroad: relying on the information available in the cluster, these entrepreneurs perceive technological learning to be less important, and they fail to pursue the acquisition of technology and skills through linkages with MNC subsidiaries. Second, MNC directors are socially disembedded, and hence have less means and incentives to establish linkages that foster technological learning. 
The findings of this study underline that in order to fully understand the effects of FDI on industrial development it is necessary to look beyond aggregated statistics and macro-economic data, corroborating it with qualitative evidence on the processes through which local organizations acquire technology, including the way in which social ties affect them. They also suggest that technological learning in Silicon Valley clones is related to the extent to which local actors are socially linked to the ICT professionals working in other locations (as argued by Saxenian, 2005 and Ó Riain, 2006) and that MNCs are socially linked to the host economy through the personal contacts of their subsidiary directors.

Becoming a successful Silicon Valley clone means not only attracting MNCs and developing local competencies, but also linking local actors to the global networks that characterise the ICT industry (Ó Riain, 2006). Ireland, Israel, India and Taiwan benefitted from the social and cultural links that connected their entrepreneurs, managers and professors to migrant ICT professionals working in the US, which provided access to information and business opportunities (Breznitz, 2007; Ó Riain, 2006; Saxenian and Hsu, 2001; Saxenian, 2005). Costa Rica does not benefit from having a large community of migrant ICT professionals in the US: the majority of Costa Rican entrepreneurs do not have social ties with ICT professionals working abroad, and this has negative effects on their technological awareness. The findings of this study suggest that helping domestic ICT producers build transnational social ties, for example by subsidising their participation to international technology fairs, 
could improve their technological awareness and thus the extent to which they attempt to acquire technology from the MNCs that operate in the Costa Rican cluster. Providing incentives for MNCs to hire local executives could contribute to reduce the socio-economic isolation in which most MNCs operate in the Costa Rican cluster, thus generating new opportunities for establishing linkages that support technological learning with local partners. 


\section{REFERENCES}

Altenburg, T., and Meyer-Stamen, J. (1999) How to promote clusters: policy experiences from Latin America. World Development, 27(9), pp. 1693-1714.

Aw, B-Y. (2002) Accumulating technology and location spillovers among firms in Taiwan's electronics industry. Journal of Development Studies, 39(1), pp. 94 - 117.

Bell, M. (1984) Learning and the accumulation of industrial technological capacity in developing countries. In: M. Fransman and K. King (eds.), Technological capability in the third world, (Hong Kong: Macmillan) pp. 138-156.

Bell, M. and Albu, M., (1999) Knowledge systems and technological dynamism in industrial clusters in developing countries. World development, 27(9), pp. 1715-1734.

Bessant, J., Rush, H., Hobday, M. (2001) Assessing technological capabilities: an audit tool. Report to the World Bank, Project on Korea and the Knowledge-Based Economy. World Bank, Washington.

Breznitz, D. (2007) Industrial R\&D as a national policy: horizontal technology policies and industry-state co-evolution in the growth of the Israeli software industry. Research Policy, 36(9), pp. 1465-1482.

CAMTIC, (2006) Database of the Costa Rican information and telecommunication technologies producers, internal document.

Caniëls, M.C.J. and Romijn, H.A. (2003) Agglomeration advantages and capability building in industrial clusters: the missing link. Journal of Development Studies, 39(3), pp. 129-154.

Cassiolato, J.E. and Lastres, H.M.M. (2000) Local systems of innovation in Mercosur countries. Industry and Innovation, 7(1), pp. 33-53. 
Castilla E., Hokyu H., and Granovetter, E. (2000) Social networks in Silicon Valley, in: C. Lee, F.W. Miller, G.M. Hancock and H.R. Rowen (eds.) The Silicon Valley edge, (Palo Alto, US: Stanford University Press) pp. 218-248.

Chudnovsky, A. López, A. Rossi, G. (2008) Foreign direct investment spillovers and the absorptive capabilities of domestic firms in the Argentine manufacturing sector (1992-2001). Journal of Development Studies, 44(5), pp. 645 - 677.

Ciravegna, L. (2009a) Academia-private sector collaborations in the Costa Rican information and communication technology (ICT) cluster. International Journal of Technology and Globalisation (IJTG) Special edition on emerging markets, 4(4), pp. 408-423.

Ciravegna, L. (2009b) Network failures in the Costa Rican ICT cluster. Working paper presented at the conference: ICT in Latin America, Federal University of Rio de Janeiro, 28 June 2009.

Ciravegna, L. and Giuliani, E. (2006) MNC-dominated clusters and the upgrading of domestic suppliers: the case of Costa Rican electronics and medical devices industries, in: R. Leoncini and S. Montresor (eds.) Dynamic capabilities between firm organization and local systems of production (London: Routledge) pp.236-262.

Criscuolo, P. and Narula, R. (2008) A novel approach to national technological accumulation and absorptive capacity: aggregating Cohen and Levinthal, European Journal of Development Research, 20(1), pp. 56-73.

Dunning, J. H., and Lundan, S.M. (2008) Multinational enterprises and the global economy, $2^{\text {nd }}$ Edition (Cheltenham: Edward Elgar) pp. 63-78; 295-411.

Dunning, J. H. and Narula, R. (2000) Industrial development, globalisation and multinational enterprises: new realities for developing countries, Oxford Development Studies, 28(2), pp. 141-167. 
Edquist, C. (1997) Introduction in C. Edquist (ed.) Systems of innovation: technologies, institutions, and organizations (London: Pinter) pp. 1-29.

Figueiredo, P.N. (2008), Industrial policy changes and firm-level technological capability development: evidence from Brazil. World Development, 36(1) pp. 55-82.

Gallagher, K.P. and Zarsky, L. (2007) The Enclave economy (London: MIT Press).

Giuliani, E. (2008) Multinational Corporations and patterns of local knowledge transfer in Costa Rican High-Tech industries. Development and Change, 39 (3), pp. 385-407.

Granovetter, M., (2005) The impact of social structure on economic outcomes. Journal of Economic Perspectives, 19(1), pp. 33-50.

Hobday, M. (1994) Export-led technology development in the four dragons: the case of electronics. Development and Change, 25, pp.333-361.

Hobday, M. and Rush, H. (2007) Upgrading the technological capabilities of foreign transnational subsidiaries in developing countries: the case of electronics in Thailand. Research Policy, 36, pp. 1335-1356.

Kesidou, E. and Romijn, H. (2008) Do local knowledge spillovers matter for development? An empirical study of Uruguay's software cluster. World Development, 36(10), pp. 2004-2028.

Kokko, A. (1994). Technology, market characteristics, and spillovers. Journal of Development Economics, 43(2), pp. 279-293.

Lall, S. and Narula, R. (2004) Foreign direct investment and its role in economic development: Do we need a new agenda? The European Journal of Development Research, 16(3), pp. 447-464.

Lall, S., (1992) Technological capabilities and industrialization. World Development, 20(2), pp. 165-186. 
Lall, S., (2003) Reinventing industrial strategy: The role of government policy in building industrial competitiveness. Report for the Intergovernmental Group on Monetary Affairs and Development (G-24).

Lopez, L., Kundu, S. and Ciravegna, L. (2009) Born global or born regional? Evidence from an exploratory study in the Costa Rican software industry. Journal of International Business Studies, 40(7), pp. 1228-1238.

Lundvall, B-Å., Johnson, B., Andersen, E.S. and Dalum, B. (2002) National systems of production, innovation and competence building. Research Policy, 31(2), pp. 213-231.

Marin, A. and Bell, M. (2006) Technology spillovers from foreign direct investment (FDI): An exploration of the active role of MNC subsidiaries in the case of Argentina in the 1990s, Journal of Development Studies 42(4), pp. 678-97.

Marshall, A. (1920) The principles of economics, (London: McMillan Press)

Monge-Gonzalez, R., Rosales Tijerino, J., and Arce-Apizar, G. (2005) Cost-benefit analysis of the free trade zones system. Washington D.C., Organization of the American States, Office for trade, growth and competitiveness.

Mytelka, L.K. and Barclay, L.A. (2004) Using foreign investment strategically for innovation. The European Journal of Development Research,16(3), pp. 531-560.

Narula, R. and Marin, A. (2003) FDI spillovers, absorptive capacities and human capital development: evidence from Argentina, MERIT Research Momorandum 200316.

Nelson, R.C. (2005) Competing for foreign direct investment: efforts to promote non-traditional FDI in Costa Rica, Brazil, and Chile. Studies in Comparative International Development, 30(3): pp. 3-38. 
Nicholson B. and Sahay, S. (2005) Human resource development policy in the context of software exports: case evidence from Costa Rica. Paper n. 23, University of Manchester: Development Informatics Group.

Ó Riain, S. (2006) Dominance and change in the global computer industry: military, bureaucratic, and network state developmentalism. Studies in Comparative International Development; 41(1), pp. 76-98.

Paus, E. and Gallagher, K. (2008). Missing links: Foreign investment and industrial development in Costa Rica and Mexico. Studies in Comparative International Development; 43(1), pp. 53-80.

Paus, E., (2005) Foreign investment, development, and globalization: can Costa Rica become Ireland? (Basingstoke, US: Palgrave Macmillan).

Perez, C. and L. Soete, (1988) Catching up in technology: entry barriers and windows of opportunity. In: G. Dosi, C. Freeman, R. Nelson, G. Silverberg and L. Soete (eds.) Technical change and economic theory, (London: Pinter) pp. 458-479.

Pietrobelli, C., Rabellotti, R. and Morrison, A. (2006) Global Value Chains and Technological Capabilities: A framework to study industrial innovation in developing countries. Working Paper n.192, CESPRI, Universitá Bocconi, Milano.

Porter, M.E. and Ketelhohn, N.W. (2002) Building a cluster: electronics and information technology in Costa Rica. Harvard Business School Case Studies, pp. 9703-422.

Porter, K., Bunker Whittington, K. and Powell, W.W. (2005) The institutional embeddedness of high tech regions: relational foundations of the Boston biotechnology community in: S. Breschi, and F. Malerba (eds.) Clusters networks and innovation (Oxford: Oxford University Press) pp. 261-294.

Powell, W. W. (1990) Neither market nor hierarchy: networks forms of organization. Research in Organizational Behavior,12, pp. 295-336. 
Rodriguez-Clare, A., (2001) Costa Rica's development strategy based on human capital and technology: how it got there, the impact of Intel, and lessons for other countries. Journal of Human Development 2(2), pp. 311-324.

Saxenian, A. (2000) The origin and dynamics of production networks in Silicon Valley. In: Kenney M. (eds.) Understanding Silicon Valley, (Palo Alto: Stanford University Press) pp. 41-164.

Saxenian, A. and Hsu, J-H. (2001) The Silicon Valley-Hsinchu connection: technical communities and industrial upgrading. Industrial and Corporate Change, 10(4), pp. 893-920.

Saxenian, A. (2005) From brain drain to brain circulation: Transnational communities and regional upgrading in India and China. Studies in Comparative International Development, 40(2), pp. 35-61.

Shrank, A., (2003) Luring, learning, and lobbying: the limits to capital mobility in the Dominican Republic. Studies in Comparative and International Development, 37(4), pp. 89-116.

Sturgeon, T. (2000). How Silicon Valley came to be, in: M. Kenney (ed.) Understanding Silicon Valley (Palo Alto: Stanford University Press), pp. 15-47.

UNCTAD (2001) World Investment Report. Promoting linkages. Geneva and New York: United Nations Conference on Trade and Development.

Uzzi, B., (1996) The sources and consequences of embeddedness for the economic performance of organizations: the network effect. American Sociological Review, 61(4), pp. 674-698.

Wade, R., (2004) Governing the market: economic theory and the role of government in East Asian industrialization, (Princeton: Princeton University Press).

The World Bank Group (2006) Costa Rica Country Economic Memorandum: The Challenges for Sustained Growth. Report No.36180-CR. 


\footnotetext{
i Interview with the ex President of Costa Rica Jose Maria Figueres shown in the video attached to Porter and Ketelhohn, 2002. Interview: Oscar Arias, President of Costa Rica, 22 February 2005.

ii The paper focuses on producers of ICT-related goods and services, ranging from microprocessors to software packages. Providers of ICT-using services, such as call centres have not been included in the definition, although they are often included in the national statistics on the ICT sector.

iii Social embeddedness also play an important role in explaining the emergence of Silicon Valley. The latter, which is the most famous ICT cluster, started as a backward region with contrast to the Boston area, where most high technology research was carried out up to the 1960s. It caught up and surpassed the Boston area thanks to the decisions of a group of individual researchers to establish themselves in California and create the company Fairchild semiconductors. Most of today's semiconductors' MNCs, such as Intel, emerged directly or indirectly from companies created by engineers that worked at Fairchild. Social contacts among them helped creating networks of interlinked companies (including MNCs and start ups) that were functional for the industrial development of Silicon Valley (Sturgeon, 2000) iv Interview: Name withheld, CEO of domestic firm, 14 August 2006.

v Interview: Name withheld, CEO of domestic firm, 10 April 2007.

vi Interview: Name withheld, CEO of domestic firm, 8 July 2007, parenthesis added by the author. vii This excludes the firms involved in product adjustment and product development linkages, and also two local companies that collaborate with universities.

viii Interview: Name withheld, CEO of domestic firm, 21 August 2006. ix Interview: Name withheld, CEO of domestic firm, 11 June 2006. x Interview: Name withheld, CEO of domestic firm, 23 April, 2007. xi Interview: Name withheld, CEO of domestic firm, 25 November 2006. BBB = Fictional name assigned to the MNC partner as required by the entrepreneur interviewed.

xii They are the six firms that have transnational social ties who ranked MNC subsidiaries as an important but not the most important source of technology for them (Table 6, third row, second column). xiii Interview: Name withheld, director of MNC subsidiary, 15 July 2007.
} 
Table 1: The Costa Rican ICT cluster in $2007^{1}$

\begin{tabular}{lcccc}
\hline & Number & $\begin{array}{l}\text { Sales (US \$ } \\
\text { million) }\end{array}$ & Employment & $\begin{array}{l}\text { Involved in } \\
\text { MNC-local firm } \\
\text { linkages }\end{array}$ \\
\hline Domestic firms & 150 & 285 & 2560 & $40 / 80$ \\
\hline MNCs & 25 & 1690 & 4345 & $4 / 25$ \\
\hline
\end{tabular}

Source: Elaboration based on interviews and information collected from Camtic

Table 2: Three types of MNC-local firms linkages

\begin{tabular}{|c|c|c|}
\hline $\begin{array}{l}\text { Type of MNC-local } \\
\text { firm linkage }\end{array}$ & $\begin{array}{l}\text { Number of } \\
\text { linkages }\end{array}$ & Technological learning processes \\
\hline Product distribution & 45 & $\begin{array}{l}\text { Standardized training courses to improve use of } \\
\text { MNC technology } \\
\text { Standardized technical assistance }\end{array}$ \\
\hline Product adaptation & 6 & $\begin{array}{l}\text { Transmission of the necessary technical } \\
\text { knowledge to modify MNC products and services } \\
\text { Customized technical assistance during product } \\
\text { development } \\
\text { Joint work with teams of engineers from the MNC } \\
\text { subsidiary } \\
\text { Training of employees in the MNC procedures }\end{array}$ \\
\hline $\begin{array}{l}\text { Product and } \\
\text { technology } \\
\text { development }\end{array}$ & 1 & $\begin{array}{l}\text { Transmission of the necessary technical } \\
\text { knowledge to develop a software application to be } \\
\text { applied to the corporate information technology } \\
\text { network } \\
\text { Technical assistance during basic research and } \\
\text { product development } \\
\text { Joint work with the R\&D teams of the MNC at both } \\
\text { subsidiary and HQ }\end{array}$ \\
\hline
\end{tabular}

Source: Elaboration based on interviews

\footnotetext{
${ }^{1}$ The paper focuses on producers of ICT-related goods and services, ranging from microprocessors to software packages. Providers of ICT-using services, such as call centres have not been included in the definition, although they are often included in the national statistics on the ICT sector.
} 
Table 3: Reasons for being part of a product distribution linkage

\begin{tabular}{|ll|}
\hline $\begin{array}{l}\text { Most important reason for being in a product } \\
\text { distribution linkage }\end{array}$ & Number of answers \\
\hline Discounts on MNC products & $19 / 45$ \\
\hline $\begin{array}{l}\text { Access to the MNC technology, which was not } \\
\text { used before the linkage }\end{array}$ & 0 \\
\hline $\begin{array}{l}\text { Access to courses to improve mastery of MNC } \\
\text { technology }\end{array}$ & $12 / 45$ \\
\hline $\begin{array}{l}\text { Achievement of the MNC Distributors' } \\
\text { Certificate }\end{array}$ & $8 / 45$ \\
\hline $\begin{array}{l}\text { Potential to engage MNCs in other types of } \\
\text { linkages }\end{array}$ & $6 / 45$ \\
\hline $\begin{array}{l}\text { Access to technical support during basic } \\
\text { research }\end{array}$ & 0 \\
\hline $\begin{array}{l}\text { Access to technical support during product } \\
\text { development }\end{array}$ & 0 \\
\hline
\end{tabular}

Source: Elaboration based on interviews

Table 4: Social ties and technological learning How important are personal contacts as means to acquire
technology, technical information and skills?

\begin{tabular}{|lc|}
\hline They are the most important source & $50 / 80$ \\
\hline Important, but not the main source & $19 / 80$ \\
\hline Not important & $11 / 80$ \\
\hline
\end{tabular}

Source: Elaboration based on interviews

Table 5: Technological awareness

\begin{tabular}{|ll|l|}
\hline $\begin{array}{l}\text { How important is it for you to } \begin{array}{l}\text { Entrepreneurs who use } \\
\text { technologically updated? }\end{array} \\
\text { Essential }\end{array}$ & $\begin{array}{l}\text { Entrepreneurs who do not } \\
\text { have transnational social } \\
\text { ties }\end{array}$ \\
\hline $\begin{array}{l}\text { Important, but other factors are } \\
\text { amportant too }\end{array}$ & $18 / 18$ & $15 / 62$ \\
\hline $\begin{array}{l}\text { Not that important, other factors } \\
\text { determine our performance }\end{array}$ & 0 & $35 / 62$ \\
\hline
\end{tabular}

Source: Elaboration based on interviews 
Table 6: Perception of MNCs as a means to foster technological learning

\begin{tabular}{|l|ll|}
\hline $\begin{array}{l}\text { Are MNCs an important means } \\
\text { to help your technological } \\
\text { learning? }\end{array}$ & $\begin{array}{l}\text { Entrepreneurs who use } \\
\text { transnational social ties to } \\
\text { acquire information }\end{array}$ & $\begin{array}{l}\text { Entrepreneurs who do not } \\
\text { have transnational social } \\
\text { ties }\end{array}$ \\
\hline Very important & $12 / 18$ & $9 / 62$ \\
\hline $\begin{array}{l}\text { Important, but there are other } \\
\text { sources from which to acquire } \\
\text { technology }\end{array}$ & $6 / 18$ & $30 / 62$ \\
\hline Not important & 0 & $23 / 62$ \\
\hline
\end{tabular}

Source: Elaboration based on interviews

Table 7: Strategy to acquire technology from MNCs

\begin{tabular}{|l|ll|}
\hline $\begin{array}{l}\text { Are you attempting to engage } \\
\text { MNCs in product adjustment or } \\
\text { product development linkages } \\
\text { as a means of technological } \\
\text { learning? }\end{array}$ & $\begin{array}{l}\text { Entrepreneurs who use } \\
\text { transnational social ties to } \\
\text { acquire information }\end{array}$ & $\begin{array}{l}\text { Entrepreneurs who do not } \\
\text { have transnational social } \\
\text { ties }\end{array}$ \\
\hline $\begin{array}{l}\text { I am already involved in these } \\
\text { linkages }\end{array}$ & $6 / 18$ & 0 \\
\hline Yes, I am trying & $6 / 18$ & $3 / 62$ \\
\hline I will try in the next future & $2 / 18$ & $15 / 62$ \\
\hline No, I am not interested & 0 & $44 / 62$ \\
\hline
\end{tabular}

Source: Elaboration based on interviews 